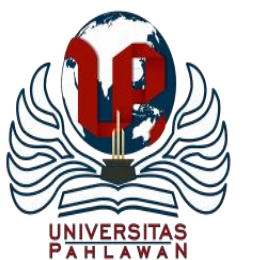

Jurnal Basicedu Volume 3 Nomor 4 Tahun 2019 Halaman 2101-2112

JURNAL BASICEDU

Research \& Learning in Elementary Education

https://jbasic.org/index.php/basicedu

\title{
PENINGKATAN MOTIVASI DAN HASIL BELAJAR MATEMATIKA PESERTA DENGAN MODEL NUMBERED HEADS TOGETHER (NHT)
}

\author{
Lely Afni Ikhwandari ${ }^{1}$, Nyoto Harjono ${ }^{2}$, Gamaliel Septian Airlanda ${ }^{3}$ \\ Universitas Kristen Satya Wacana, Jawa Tengah, Indonesia ${ }^{1,2,3}$ \\ Email : 292013252@ student.uksw.edu ${ }^{1}$, ,nyotoharjono@uksw.edu ${ }^{2}$. gama.airlanda@uksw.edu $^{3}$
}

\begin{abstract}
Abstrak
Tujuan penelitian ini adalah untuk meningkatkan otivasi dan hasil belajar matematika peserta didik kelas 4 SD Negeri Gedong 2 Banyu Biru dengan model Numbered Heads Together (NHT) pada semester I, tahun pelajaran 2019/2020. Desain penelitian ini adalah penelitian tindakan kelas (PTK). Teknik pengumpulan data dengan cara observasi dan evaluasi. Instrumen pengumpulan data dengan lembar observasi, angket, dan tes tertulis berupa pilihan ganda. Teknik analisis data menggunakan deskriptif komparatif yang berupa presentasE ari data yang diperoleh melalui dari angket motivasi dan hasil belajar matematika antara pra siklus dan setelah siklus. Motivasi dan hasil belajar siswa mengalami peningkatan yang berarti. Motivasi pada pra siklus yang mencapai kategori tinggi sebesar $22 \%$ atau 5 dari 23 peserta dididk. Setelah dilakukan tindakan siklus I untuk meningkatkan motivasi mencapai kategori tinggi sebesar 52\% atau 12 peserta dididk dan pada siklus II untuk lebih meningkatkan motivasi mencapai kategori tinggi sebesar $87 \%$ atau 20 peserta dididk. Setelah diberikan tindakan pembelajaran menggunakan model Numbered Heads Together (NHT), pada siklus I terjadi peningkatan hasil belajar peserta didik yang ditunjukkan oleh kenaikan persentase hasil belajar peserta didik. Sebelum tindakan sebanyak 10 peserta didik (43\%) yang tuntas dari 23 peserta didik. Setelah diberikan tindakan pada siklus I, terjadi peningkatan jumlah yang tuntas menjadi 15 peserta didik (65\%). Pada siklus II terjadi peningkatan jumlah yang tuntas menjadi 20 (87\%). Hasil ini menunjukkkan bahwa adanya peningkatan motivasi dan hasil belajar matematika peserta didik pada 4 SD Negeri Gedong 2 Banyu Biru dengan menggunakan model Numbered Heads Together (NHT)
\end{abstract}

Kata Kunci : NHT, Motivasi,Hasil Belajar

\begin{abstract}
Abstrack
The purpose of this study is to improve the mathematical motivation and learning outcomes of grade 4 students of SDN Gedong 2 Banyu Biru with the Numbered Heads Together (NHT) model in the first semester, 2019/2020 school year. The design of this study is classroom action research (CAR). Data collection techniques by observation and evaluation. Data collection instruments with observation sheets, questionnaires, and written tests in the form of multiple choice. The data analysis technique uses comparative descriptive in the form of presentation of data obtained through the questionnaire of motivation and mathematics learning outcomes between pre-cycle and after-cycle. Motivation and student learning outcomes have increased significantly. Motivation in the pre cycle which reached a high category of $22 \%$ or 5 out of 23 participants. After taking the first cycle to increase motivation to reach the high category by $52 \%$ or 12 students and in the second cycle to further increase motivation to reach the high category by $87 \%$ or 20 students. After being given learning actions using the Numbered Heads Together (NHT) model, in cycle I there was an increase in student learning outcomes as indicated by an increase in the percentage of student learning outcomes. Before the action as many as 10 students (43\%) were completed out of 23 students. After being given action in the first cycle, there was an increase in the number of completeness to 15 students (65\%). In cycle II an increase in the number of completions to 20 (87\%). These results show that there is an increase in motivation and learning outcomes of students in mathematics using the Numbered Heads Together (NHT) model.
\end{abstract}

Keywords: motivation, learning outcome, numbered heads together model

@ Jurnal Basicedu Prodi PGSD FIP UPTT 2019

$\triangle$ Corresponding author :

Address :

Email :

ISSN 2580-3735 (Media Cetak)

Phone

ISSN 2580-1147 (Media Online) 


\section{PENDAHULUAN}

Motivasi belajar peserta didik sangat menentukan keberhasilan yang dicapai oleh peserta didik tersebut. Peserta didik yang memiliki motivasi belajar tinggi akan mampu meraih hasil belajar yang tinggi, tetapi sebaliknya, peserta didik yang motivasi belajarnya rendah cendrung mendapatkan hasil belajar yang rendah pula dan akan mengalami kesulitan belajar yang lebih tinggi. Uno (2013:1) motivasi adalah dorongan dasar yang menggerakkan seseorang bertingkah laku. Dorongan ini berada pada diri seseorang yang menggerakkan untuk melakukan sesuatu yang sesuai dengan dorongan didalam dirinya berupa keinginan dan kebutuhan peserta didik untuk datang ke sekolah, mengikuti pelajaran, mengerjakan tugas, mengulang pelajaran dan membaca buku referensi tanpa dorongan orang lain atau dari luar.

Menurut Yamin (2012:196), seseorang yang tidak mempunyai motivasi dalam belajar tidak mungkin melakukan aktifitas belajar. Sardiman (2012: 40) menjelaskan bahwa peserta didik dikatakan berhasil dalam belajar jika ada motivasi dari dirinya sendiri untuk belajar, sehingga peserta didik mengetahui apa yang akan dipelajari dan memahami mengapa hal tersebut perlu untuk dipelajari. Tinggi rendah motivasi belajar dapat terlihat dari sikap yang ditunjukkan peserta didik pada saat pelaksanaan kegiatan belajar mengajar seperti minat, semangat, tanggung jawab, rasa senang dalam mengerjakan tugas dan reaksi yang ditunjukkan pada peserta didik terhadap stimulus yang diberikan guru (Sudjana, 2013: 61).Rendahnya motivasi belajar peserta didik akan menghambat pencapaian tujuan pendidikan dan harus ditangani dengan tepat. Seseorang yang memiliki inteligensia yang cukup tinggi, boleh jadi gagal karena kekurangan motivasi, hasil belajar akan optimal kalau ada motivasi yang tepat (Sardiman, 2012: 75).

Berdasarkan hasil observasi dan pengamatan di kelas 4 SDN Gedong 2 Banyu Biru Kabupaten Semarang menunjukkan bahwa motivasi peserta didik di kelas 4 dalam mengikuti proses pembelajaran tersebut rendah. peserta didik pasif dalam proses pembelajaran. Pada saat guru memberikan penjelasan tentang jawaban soal evaluasi yang dikerjakan, banyak peserta didik yang memperhatikan namun tidak terlalu peduli dengan apa yang disampaikan oleh guru. Mereka tidak ikut serta dalam pembahasan jawaban, hanya beberapa peserta didik yang aktif dan ikut membahas jawaban. Peserta didik yang aktif kebanyakan peserta didik yang duduk di depan guru. Proses pembelajaran sudah berjalan dengan baik, namun masih terdapat beberapa permasalahan yang terjadi selama kegiatan belajar mengajar, salah satunya yaitu kurang tepatnya model pembelajaran yang digunakan dalam menyampaikan materi matematika sehingga menyebabkan peserta didik menjadi kurang terlibat aktif dalam proses pembelajaran yang berdampak pada rendahnya hasil belajar, Guru menggunakan metode ceramah yang bervariasi dengan model tanya jawab dan penugasan. saat menjelaskan materi belajar melalui ceramah. Peserta didik tidak didorong untuk aktif belajar menggunakan kerja ilmiah. Aktivitas pembelajaran didominasi oleh guru, aktivitas dalam pembelajaran, guru tidak pernah mencoba memberikan permasalahan kepada peserta didik untuk diselesaikan, tidak ada kegiatan bekerja berkelompok, sehingga seluruh kegiatan belajar dikerjakan oleh guru.

Hasil wawancara dengan guru kelas 4 SD Negeri Gedong 2 Banyu Biru masih banyak peserta didik yang mengalami kesulitan tentang soal pemecahan masalah dan soal berpikir kreatif 


\section{Peningkatan moivasi dan hasil belajar matematika peserta didik dengan model NHT-Lely Afni Ikhwandari, Nyoto Harjono, Gamaliel Septian Airlanda}

pada materi pecahan yang diperoleh data bahwa nilai rata-rata peserta didik masih di bawah KKM, selain itu diperkuat dengan data hasil wawancara anak secara acak ternyata memang anak anak juga mengalami kesulitan pada materi pecahan dengan soal pemecahan masalah serta masih masih kebingungan dalam menyelesaikan soal yang berpikir kreatif. Peserta didik merasa kesulitan untuk mengerjakan soal-soal yang membutuhkan pemikiran tingkat tinggi. Guru hanya memberi materi pelajaran dan rumus-rumus, peserta didik memperhatikan dan mencatat, guru memberikan cara menyelesaikan contoh soal, kemudian peserta didik mencatat dan selanjutnya mengerjakan soalsoal latihan yang biasa. Selain itu, ada juga peserta didik yang hanya mau mencatat ketika guru menyuruh, bahkan ada yang tidak mengerjakan soal ketika teman lain mengerjakan. Tingkat motivasi peserta didik dari 23 peserta didik terdapat 5 peserta didik atau 22\% memiliki tingkat motivasi peserta didik pada kategori tinggi, sedangkan 8 peserta didik atau $35 \%$ memiliki tingkat motivasi peserta didik pada kategori sedang, dan 10 peserta didik atau $43 \%$ memiliki tingkat motivasi peserta didik pada kategori rendah.

Hal ini berdampak pada hasil belajar peserta didik yang relatif rendah dan belum mencapai kriteria ketuntasan minimum (KKM) dimana setiap peserta didik harus memperoleh nilai yang telah ditetapkan oleh sekolah yaitu 70 dan dari 23 peserta didik hanya 10 peserta didik atau $43 \%$, peserta didik yang dapat mencapai nilai KKM tersebut, dari seluruh peserta didik kelas 4 SD Negeri Negeri Gedong 2 Banyu Biru Kabupaten Semarang dan 13 peserta didik atau $57 \%$ peserta didik sebelum mencapai KKM. Dari hasil tersebut maka hasil belajar matematika di kelas 4 SD Negeri Gedong 2 Banyu Biru masih belum mencapai tujuan yang diharapkan, selain itu peserta didik juga masih cenderung pasif dalam mengikuti kegiatan pembelajaran.

Peningkatan hasil belajar dengan model pembelajaran dapat dipadu dengan berbagai model pembelajaran agar pembelajaran lebih bervariasi. Model pembelajaran adalah kerangka konseptual yang melukiskan prosedur yang sistematis dalam mengorganisasikan pengalaman belajar untuk mencapai tujuan belajar tertentu dan berfungsi sebagai pedoman bagi merencanakan aktivitas belajar mengajar (Ngalimun, 2014:8).

Model pembelajaran pembelajaran aktif yang dapat mengatasi permasalahan tersebut adalah model pembelajaran Numbered Heads Together (NHT) adalah suatu tipe dari pembelajaran kooperatif pendekatan struktural yang memberikan kesempatan kepada peserta didik untuk saling membagikan ide-ide dan mempertimbangkan jawaban yang paling tepat. Sebuah tekhnik pembelajaran kooperatif dimana peserta didik, bukan guru, yang memiliki tanggung jawab lebih besar dalam pelaksanaan pembelajaran. Model Numbered Heads Together (NHT) pada dasarnya dibuat agar peserta didik dapat bekerja salin bergantung pada kelompokkelompok kecil secara kooperatif. Penerapanpenerapan pembelajaran dengan cara mengelompokkan peserta didik heterogen, tugas setiap kelompok ada yang sama ada yang berbeda. Setelah memperoleh tugas, setiap kelompok bekerja sama dalam bentuk kerja individual dan diskusi (Slameto,2015:438).

Pembelajaran dengan model Numbered Heads Together (NHT) akan menumbuhkan kerja sama antar peserta didik, peserta didik berlomba untuk aktif dalam kegiatan pembelajaran karena peran anggota kelompok sangat penting dalam proses pembelajaran. Selain kerja sama antar peserta didik dengan peserta didik, juga akan terjalin kerja sama antara guru dengan peserta didik. Ngatini (2012:153) bahwa model 


\section{Peningkatan moivasi dan hasil belajar matematika peserta didik dengan model NHT - Lely Afni Ikhwandari, Nyoto Harjono, Gamaliel Septian Airlanda}

pembelajaran Numbered Heads Together (NHT) mengajarkan kepada peserta didik agar dapat bekerja sama dan selalu siap untuk memberikan jawaban terhadap pertanyaan yang diberikan guru. Dengan hal ini maka peserta didik akan menjadi termotivasi dan lebih disiplin dalam mengerjakan tugas dan memperhatikan apa yang diinstruksiskan guru sehingga hasil belajar akan menjadi baik.

Menurut Sardiman (2012:73) motivasi diartikan sebagai daya upaya yang mendorong seseorang untuk melakukan sesuatu dan digunakan sebagai daya penggerak di dalam subjek untuk melakukan aktifitas-aktifitas tertentu demi mencapai suatu tujuan. Dalam kegiatan belajar mengajar, motivasi dikatakan sebagai keseluruhan daya penggerak di dalam diri peserta didik yang menimbulkan kegiatan belajar, yang akan menjamin kelangsungan kegiatan belajar peserta didik dan memberikan arah pada kegiatan belajarnya, sehingga tujuan yang diinginkan peserta didik dapat tercapai lebih lanjut.

Menurut Donald (dalam Sardiman, 2012:73), motivasi merupakan perubahan energi dalam diri seseorang yang ditandai dengan munculnya feeling yang didahului dengan tanggapan terhadap adanya tujuan yang ingin dicapainya. Motivasi merupakan salah satu faktor internal penyebab kesulitan belajar peserta didik. Motivasi sebagai faktor inner (batin) berfungsi menimbulkan, mendasari, mengarahkan perbuatan belajar. Motivasi dapat menentukan baik tidaknya dalam mencapai tujuan sehingga semakin besar motivasinya akan semakin besar kesuksesan belajarnya. Seorang yang besar motivasinya akan giat berusaha, tampak gigih tidak mau menyerah giat membaca buku untuk meningkatkan prestasinya untuk memecahkan masalahnya. Sebaliknya mereka yang motivasinya rendah tampak acuh tak acuh, mudah putus asa, perhatiannya tidak tertuju pada pembelajaran, suka mengganggu kelas, sering meninggalkan pelajaran akibatnya banyak mengalami kesulitan belajar. (Ahmadi dan Supriyono, 2013: 83). Suhana (2014:24) bahwa motivasi belajar merupakan kekuatan (power motivation), daya pendorong (driving force), atau alat pembangun kesediaan dan keinginan yang kuat dalam diri peserta didik untuk belajar secara aktif, kreatif, efektif, inovatif, dan menyenangkan dalam rangka perubahan perilaku baik dalam aspek kognitif, afektif, dan psikomotor. Motivasi Belajar adalah dorongan internal dan eksternal pada peserta didik yang sedang belajar untuk mengadakan perubahan tingkah laku pada umumnya dengan beberapa indikator atau unsur yang mendukung (Uno, 2013:23).

Berdasarkan beberapa pendapat ahli di atas, motivasi dapat disimpulkan sebagai dorongan yang ada dalam diri setiap individu, sehingga menimbulkan perilaku untuk mempertahankannya, memberikan energi serta arah tertentu untuk mencapai tujuan yang diinginkan termasuk perilaku belajar matematika.

Motivasi belajar adalah dorongan internal dan eksternal terhadap peserta didik yang sedang dalam proses belajar untuk mengadakan perubahan tingkah laku, pada umunya dengan beberapa indikator atau unsur yang mendukung. Menurut (Uno,2013:186) indikator-indikator motivasi belajar dapat diklasifikasikan sebagai berikut;1) Adanya hasrat dan keinginan berhasil;2) Adanya dorongan dan kebutuhan dalam belajar;3) Adanya harapan dan cita-cita masa depan;4) Adanya penghargaan dalam belajar;5) Adanya kegiatan yang menarik dalam belajar;6) Adanya lingkungan belajar yang kondusif, sehingga memungkinkan seseorang peserta didik dapat belajar dengan baik.

Sardiman (2011: 83) indikator motivasi meliputi;1) Tekun menghadapi tugas. Seorang peserta didik dikatakan tekun apabila ia dapat bekerja terus-menerus dalam waktu yang lama, 


\section{Peningkatan moivasi dan hasil belajar matematika peserta didik dengan model NHT - Lely Afni Ikhwandari, Nyoto Harjono, Gamaliel Septian Airlanda}

tidak pernah berhenti sebelum selesai;2) Ulet menghadapi kesulitan. peserta didik menunjukkan keuletannya apabila setiap kesulitan dihadapinya dengan tidak mudah putus asa dan tidak cepat puas dengan prestasi yang telah dicapainya;3) Menunjukkan minat terhadap bermacam-macam masalah. peserta didik menunjukkan kemauan untuk menyelesaikan berbagai macam permasalahan yang belunm tentu disenangi oleh orang lain;4) Lebih senang bekerja mandiri. Dalam menghadapi sebuah persoalan, peserta didik lebih senang bekerja mandiri dengan kemampuan yang dimilikinya;5) Cepat bosan pada tugas-tugas yang rutin. peserta didik merasa bosan dengan hal-hal yang sifatnya berulang-ulang begitu saja sehingga kurang dapat memunculkan kreatifitas yang diperlukan oleh peserta didik;6).Dapat mempertahankan pendapatnya. Ketika peserta didik sudah merasa yakin terhadap apa yang dikehendakinya, dia akan mempertahankan keyakinan tersebut;7)Tidak mudah melepaskan hal yang diyakini. Setelah merasa yakin terhadap sesuatu dan mempertahankannya, maka peserta didik juga tidak akan mudah melepaskan hal-hal yang diyakini itu;8)Senang mencari dan memecahkan masalah soal-soal. peserta didik dikatakan termotivasi dalam belajar apabila dia selalu mencari dan memecahkan masalah soal-soal yang tidak semua peserta didik melakukannya.

Hasil belajar menurut Susanto (2013: 5) adalah kemampuan yang diperoleh anak setelah melalui kegiatan belajar. Oleh karena itu hasil belajar dapat diartikan bahwa anak mencapai hasil belajar jika anak telah mencapai tujuan pembelajaran sehingga menghasilkan perubahan tingkah laku peserta didik. Purwanto (2013:46) bahwa hasil belajar adalah perubahan perilaku peserta didik akibat belajar. Perubahan perilaku disebabkan karena dia mencapai penguasaan atas sejumlah bahan yang diberikan dalam proses belajar mengajar. Lebih lanjut lagi Purwanto menyatakan bahwa macam-macam hasil belajar meliputi pemahaman konsep aspek kogntif, keterampilan proses aspek psikomotorik dan sikap peserta didik aspek afektif. Hasil belajar merupakan hasil dari suatu interaksi tindak belajar dan tindak mengajar. Dari sisi guru, tindak mengajar diakhiri dengan proses evaluasi hasil belajar.

Dari sisi peserta didik, hasil belajar merupakan berakhirnya penggal dan puncak proses belajar. Dimyati dan Mudjiono (2013: 3) Hasil belajar adalah perubahan perilaku secara keseluruhan bukan hanya salah satu aspek potensi kemanusiaan saja (Suprijono, 2012: 7). Perubahan yang dihasilkan peserta didik ini secara menyeluruh dalam setiap aspek. Tidak hanya dalam bidang ketrampilan saja namun setiap bidangnya juga dapat mempengaruhi hasil belajar dari peserta didik. Hasil belajar dipengaruhi oleh beberapa faktor, baik yang bersifat internal mapun eksternal. Hasil belajar merupakan suatu puncak proses belajar. Proses belajar ini ini dapat menghasilkan suatu pengetahuan dan memberikan suatu perubahan bagi peserta didik. Bentuk perubahan dari hasil belajar yang didapat ini merupakan suatu tujuan dari kegiatan pembelajaran yang sudah dilakukan.

Hasil belajar merupakan pengukuran dari penilaian kegiatan belajar atau proses belajar yang dinyatakan dalam symbol, huruf maupun kalimat yang menceritakan hasil yang sudah dicapai oleh setiap anak pada periode tertentu menurut Majid (2014: 28) Bloom (Suprijono, 2012: 6), mengatakan hasil belajar mencakup kemampuan kognitif, afektif, dan psikomotorik. Domain kognitif meliputi: knowledge (pengetahuan, ingatan), comprehension (pemahaman, menjelaskan, meringkas, contoh), application (menerapkan), analysis (menguraikan, menentukan hubungan), synthesis (mengorganisasikan, merencanakan, membentuk, bangunan baru), dan 


\section{Peningkatan moivasi dan hasil belajar matematika peserta didik dengan model NHT - Lely Afni Ikhwandari, Nyoto Harjono, Gamaliel Septian Airlanda}

evaluation (menilai). Domain afektif meliputi: receiving (sikap menerima), responding (memberikan respon), valuing (nilai), organization (organisasi), characterization (karakterisasi). Sedangkan domain psikomotor meliputi keterampilan produktif, teknik, fisik, sosial, manajerial dan intelektual.

Penggunaan model pembelajaran atau pemilihan model pembelajaran yang menarik agar dapat memicu peserta didik untuk ikut serta secara aktif dalam kegiatan pembelajaran yaitu model pembelajaran aktif. Pada dasarnya pembelajaran aktif adalah suatu pembelajaran yang mengajak peserta didik untuk belajar secara aktif. Di mana peserta didik di ajak untuk turut serta dalam proses pembelajaran, tidak hanya mental akan tetapi juga melibatkan fisik. Model pembelajaran pembelajaran aktif yang dapat mengatasi permasalahan tersebut yaitu model pembelajaran Numbered Heads Together (NHT).

Menurut Ngalimun (2014:169) model pembelajaran Numbered Heads Together (NHT) adalah salah satu tipe dari pembelajaran kooperatif dengan sintaks : pengarahan, buat kelompok heterogen dan tiap peserta didik memiliki nomor tertentu. Pembelajaran kooperatif merupakan strategi pembelajaran yang mengutamakan adanya kerjasama antar peserta didik dala kelompok untuk mencapai tujuan pembelajaran. Para peserta didik dibagi menjadi kelompok-kelompok kecil dan diarahkan untuk mempelajari materi pelajaran yang telah ditentukan.

Model pembelajaran Numbered Heads Together (NHT) adalah pembelajaran dengan menggunakan model Numbered Heads Together (NHT) diawali dengan Numbering (Suprijono, 2013:92). Model pembelajaran Numbered Heads Together (NHT) adalah varian dari diskusi kelompok. Huda (2013:203) mengatakan bahwa metode yang dikembangkan oleh Russ Frank ini cocok untuk memastikan akuntabilitas individu dalam diskusi kelompok. Tujuan Numbered Heads Together (NHT) ini adalah memberikan kesempatan kepada peserta didik untuk saling berbagi gagasan dan mempertimbangkan jawaban yang paling tepat.

Menurut Huda (2014:130) pada dasarnya Numbered Heads Together (NHT) merupakan varian dari diskusi kelompok. Teknis pelaksanaanya hampir sama dengan diskusi kelompok. Pertama-tama guru meminta peserta didik untuk duduk berkelompok-kelompok. Masing-masing anggota diberi nomor. Setelah selesai guru memanggil nomor untuk mempresentasikan hasil diskusinya. Guru tidak memberitahukan nomor berapa yang akan berpresentasi selanjutnya. Begitu seterusnya hingga semua nomor terpanggil. Pemanggilan secara acak ini akan memastikan semua peserta didik benar-benar terlibat dalam diskusi. Adapun tujuan dari metode pembelajaran Numbered Heads Together (NHT) ini adalah untuk mengembangkan kerja tim, ketrampilan belajar kooperatif, dan menguasai pengetahuan secara mendalam yang tidak mungkin diperoleh bila mereka mencoba untuk mempelajari semua materi sendirian (Trianto, 2010: 85).

Model pembelajaran Numbered Heads Together (NHT) akan dapat menambah motivasi, rasa percaya diri, toleransi, kerjasama dan juga pemahaman materi peserta didik. Tujuan dari penelitian ini adalah untuk 1) mengetahui peningkatan motivasi belajar matematika dengan menerapan model Numbered Heads Together (NHT) pada peserta didik kelas 4 SD N Gedong 2 Banyu Biru Semester I Tahun Pelajaran 2019/2020. 2) mengetahui peningkatan hasil belajar matematika melalui motivasi belajar menggunakan model Numbered Heads Together (NHT) pada peserta didik kelas 4 SD N Gedong 2 Banyu Biru Semester I Tahun Pelajaran 2019/2020. Berdasarkan tujuan pelaksanaan 
penelitian yang telah disusun maka hipotesis tindakan dari penelitian ini adalah Penerapan model Numbered Heads Together (NHT) dapat 1) meningkatkan motivasi matematika peserta didik kelas 4 SD N Gedong 2 Banyu Biru Semester I Tahun Pelajaran 2019/2020. 2) Peningkatan motivasi belajar melalui model Numbered Heads Together (NHT) dapat meningkatkan hasil belajar matematika peserta didik kelas 4 SD N Gedong 2 Banyu Biru Semester I Tahun Pelajaran 2019/2020

\section{METODE}

Jenis penelitian ini adalah Penelitian Tindakan Kelas (PTK) pada pembelajaran matematika menggunakan model Numbered Heads Together (NHT). Penelitian ini dilaksanakan di kelas 4 SD N Gedong 2 Banyu Biru. Subjek penelitian ini yaitu peserta didik kelas 4 SD N Gedong 2 Banyu Biru Semester I Tahun Pelajaran 2019/2020 dengan jumlah peserta didik kelas 4 yang berjumlah 23 peserta didik, terdiri dari 13 peserta didik laki-laki dan 10 peserta didik perempuan. Data berasal dari peserta didik kelas 4, guru kelas 4, teman sejawat atau observer, dan dokumen. Teknik pengumpulan data menggunakan angket motivasi, tes, observasi, wawancara.

Analisis data yang digunakan adalah analisis data kuantitatif dan kualitatif. Penelitian tindakan kelas ini dilaksanakan selama dua siklus masing-masing siklus tiga pertemuan. Setiap pertemuan terdiri dari perencanaan, pelaksanaan, observasi, dan refleksi.

\section{HASIL DAN PEMBAHASAN}

Hasil Analisis dalam penelitian ini menggunakan annalisis komparatif dengan membandingkan hasil dari setiap data yang diperoleh untuk melihat adanya suatu peningkatan pada evaluasi. Hasil perbandingan akan dijabarkan dengan menggunakan pendekatan deskriptif kualitatif. Berikut ini penjelasan analisi komparatif pelaksanaan dan hasil tindakan di bawah ini:

Data analisis komparatif yang dilakukan terhadap proses penelitian pada peserta didik kelas 4 SDN Gedong 2 Banyu Biru dengan pemberian tindakan melalui model pembelajaran Numbered Heads Together (NHT) yang diuraikan dalam hasil angket pra siklus, siklus I dan siklus II sehingga dapat dikethui peningkatan motivasi belajar matematika. Perbandingan hasil analisis angket motivasi belajar peserta didik pada pra siklus, siklus I dan siklus II dapat dilihat pada tabel 1 sebbagai berikut:

Tabel 1

\section{Perbandingan Hasil Data Motivasi Belajar Peserta Didik}

\begin{tabular}{ccccccccc}
\hline \multirow{2}{*}{ No } & Rentang & Kategori & \multicolumn{2}{c}{ Pra Siklus } & \multicolumn{2}{c}{ Siklus I } & \multicolumn{2}{c}{ Siklus II } \\
\cline { 4 - 9 } & Skor & Motivasi Belajar & Jumlah & $\%$ & Jumlah & $\%$ & Jumlah & $\%$ \\
\hline 1 & $60-80$ & Tinggi & 5 & $22 \%$ & 12 & $52 \%$ & 20 & $87 \%$ \\
\hline 2 & $30-59$ & Sedang & 8 & $35 \%$ & 9 & $39 \%$ & 3 & $13 \%$ \\
\hline 3 & $0-29$ & Rendah & 10 & $43 \%$ & 2 & $9 \%$ & 0 & $0 \%$ \\
\hline \multicolumn{2}{r}{ Jumlah } & & 23 & $100 \%$ & 23 & $100 \%$ & 23 & $100 \%$ \\
\hline
\end{tabular}

Dari tabel 1 di atas, dapat diketahui bahwa dari pra siklus sampai pelaksanaan siklus II terjadi peningkatan terhadap motivasi belajar peserta didik. Pada pra siklus, peserta didik yang berada dalam kategori tinggi sebanyak 5 peserta didik atau $22 \%$ dari jumlah peserta didik. Kemudian setelah dilakukan siklus I, peserta didik yang berada pada kategori tinggi meningkat menjadi 12 peserta didik atau 52\% selanjutnya meningkat menjadi 7 peserta didik atau $20 \%$. Persentase ini meningkat kembali pada siklus II sebesar $35 \%$ atau 8 peserta didik sehingga didapati peserta didik yang berada dalam kategori tinggi sebanyak 20 peserta didik 


\section{Peningkatan moivasi dan hasil belajar matematika peserta didik dengan model NHT - Lely Afni Ikhwandari, Nyoto Harjono, Gamaliel Septian Airlanda}

dengan persentase sebesar $87 \%$. Selanjutnya peserta didik yang berada dalam kategori sedang pada pra siklus menunjukkan persentase sebesar $35 \%$ atau 8 peserta didik dalam kategori sedang. Setelah dilakukan siklus I, persentase ini meningkat sebesar $39 \%$ atau 9 peserta didik dalam kategori sedang sehingga persentasenya menjadi $4 \%$. Kemudian, peserta didik yang berada dalam kategori rendah yang ditunjukkan pada pra siklus menunjukkan persentase yang cukup banyak yaitu $43 \%$ dengan jumlah 10 peserta didik. Setelah dilakukan siklus I, persentase ini menurun sebesar $9 \%$ atau 2 peserta didik dalam kategori rendah. Setelah dilakukan siklus II jumlah peserta didik dalam kategori rendah menurun menjadi 0 peserta didik dengan persentase sebesar 0\%. Data analisis komparatif pada hasil tindakan yang dilakukan terhadap hasil penelitian peserta didik kelas 4 SDN Gedong 2 Banyu Biru dengan pemberian tindakan melalui model pembelajaran Numbered Heads Together (NHT). Pada analisis ini akan menguraikan tentang perbandingan hasi belajar serta ketuntasan matematika pada kondisi awal, siklu I dan siklus II. Sehingga dapat diketahui perbandingan peningkatan hasi belajar matematika yang diperoleh pserta didik sebelum pelaksanaan dan setelah pelaksanaan tindakan. Perbandingan peningkatan hasil belajar matematika pada pra siklus,siklus I dan siklus II dapat dilihat pada tabel

2 sebagai berikut:

Tabel 2 Perbandingan Hasil Belajar Matematika Pra Siklus, Siklus I dan Siklus II

\begin{tabular}{|c|c|c|c|c|c|c|c|}
\hline \multirow[t]{2}{*}{ No } & \multirow[t]{2}{*}{ Kriteria } & \multicolumn{2}{|c|}{ Pra siklus } & \multicolumn{2}{|c|}{ Siklus I } & \multicolumn{2}{|c|}{ Siklus II } \\
\hline & & Jumlah & Persentase & Jumlah & Persentase & Jumlah & Persentase \\
\hline 1 & Tuntas & 10 & $43 \%$ & 15 & $65 \%$ & 20 & $87 \%$ \\
\hline 2 & Tidak tuntas & 13 & $57 \%$ & 8 & $35 \%$ & 3 & $13 \%$ \\
\hline & Jumlah & 23 & $100 \%$ & 23 & $100 \%$ & 23 & $100 \%$ \\
\hline & ai Tertinggi & \multicolumn{2}{|c|}{85} & \multicolumn{2}{|r|}{90} & \multicolumn{2}{|c|}{95} \\
\hline & i Terendah & \multicolumn{2}{|c|}{45} & \multicolumn{2}{|r|}{55} & \multicolumn{2}{|r|}{65} \\
\hline & i Rata-Rata & \multicolumn{2}{|c|}{65} & \multicolumn{2}{|r|}{73} & \multicolumn{2}{|c|}{81} \\
\hline
\end{tabular}

Tabel 2 dapat dilihat adanya peningkatan jumlah ketuntasan hasil belajar peserta didik. yang semula pada pra siklus sebelum diadakannya tindakan, ketuntasan peserta didik hanya mencapai $43 \%$, setelah digunakan model pembelajaran Numbered Heads Together (NHT) meningkan menjadi $65 \%$ kemudian setelah tindakan dilakukan dalam 2 siklus hasil belajar peserta didik meningkat lagi mencapai $87 \%$ dari jumlah keseluruhan peserta didik. Peningkatan nilai tertinggi dan nilai terendah pada setiap siklus selalu meningkat. Pada pra siklus nilai tertinggi 85 dan nilai terendah 45 dan nilai rata-rata 65 , setelah dilakukan tindakan pada siklus II nilai tertinggi 90 dan nilai terendah 55 dan nilai rata-rata 73, pada siklus II nilai tertinggi 95 dan nilai terendah adalah 65 dan nilai rata-rata 81 .
Berdasarkan hasil observasi yang dilakuan oleh penilit di kelas 4 SDN Gedong 2 Banyu Biru, diketahui sebelum tindakan penelitian dilakukan pembelajaran yang diterapakan guru yaitu kurangnya apersepsi diawal pembelajaran dengan pemberian stimulus berupa pertanyaan pertanyaan yang dapat mengarahkan peserta didik kedalam permasalahan yang akandipecahkan nantinya oleh peserta didik, kemudian pengajuan pertanyaan atau masalah ini sesuai dengan sintak model model pembelajaran Numbered Heads Together (NHT) pada tahap pertama, selain itu diketahui bahwa guru kurang apersepsi dalam pembelajaran yang dapat memunculkan ketertarikan peserta didik dalam belajar, tidak ada motivasi yang menyenangkan karena belajar masih sebatas mengikuiti persis apa yang ada dari buku 


\section{Peningkatan moivasi dan hasil belajar matematika peserta didik dengan model NHT - Lely Afni Ikhwandari, Nyoto Harjono, Gamaliel Septian Airlanda}

pengangan peserta didik. Hal ini dal pemanfaatan media pembelajaran sesuai dengan model pembelajaran Numbered Heads Together (NHT). Karena apabila jika guru dalam mengajar menggunakan media,maka materi pembelajaran akan lebih mudah dipahami oleh peserta didik.Proses pembelajaran yang demikian ini berdampak pada respon peserta didik yang cenderung kurang aktif. Tidak ada aktifitas yang membangun motivasi dan kretifitas peserta didik dalam menolah pengetahuan. Hal tersebut menjadi faktor yang memengaruhi hasil belajar matematika pada peserta didik kleas 4 .

Dengan kondisi tersebut maka peniliti perlu melaksanakan tindakan perbaikan untuk meningkatkan motivasi dan hasil belajar matematika dengan model pembelajaran Numbered Heads Together (NHT). Melalui pembelajaran Numbered Heads Together (NHT) ini peserta didik dilibatkan secara aktif dalam mengikuti kegiatan proses pembelajaran yang meliputi: menyimak,mengamati,merefleksi pengetahuan yang dimiliki, besdiskusi untuk menyelesaikan masalah,mempresentasikan hasil diskusi dan salaing bertanya jawab dalam memberikan tanggapan. Dengan menggunakan model pembelajaran Numbered Heads Together (NHT) ini antusias peserta didik dalam pembelajaran meningkat. Meningkatnya motivasi belajar peserta didik berdampak pada hasil belajar matematika. Hal ini dilihat dari peningkatan hasil rata-rata.

Fokus perbaikan pada penelitian tindakan ini adalah peningkatan motivasi dan hasil belajar matematika peserta didik kelas 4 SDN Gedong 2 Banyu Biru melalui model pembelajaran Numbered Heads Together (NHT). Berdasarkan hasil analisis data yang telah diperoleh dari pra siklus, siklus I dan siklus II motivasi dan hasil belajar peserta didik mengalami peningkatan yang cukup signifikan. Sebelum dilakukan tindakan atau pada pra siklus terdapat 5 peserta didik atau (22\%) yang memiliki motivasi pada kategori tinggi, sedangkan 8 peserta didik atau (35\%) memiliki motivasi pada kategori sedang, 10 peserta didik atau (43\%) memiliki motivasi pada kategori rendah kemudian dilaksanakan siklus I terdapat 12 peserta didik atau (52\%) yang memiliki motivasi pada kategori tinggi, sedangkan 9 peserta didik atau (39\%) memiliki motivasi pada kategori sedang, 2 peserta didik atau( 9\%) memiliki motivasi pada kategori rendah. Berarti terjadi peningkatan sebanyak $(30 \%)$. Akan tetapi hasil yang diperoleh pada siklus I belum memenuhi target sesuai dengan indikator kerja yang telah dibuat yaitu ketuntasan mencapai $(80 \%)$ atau lebih dari keseluruhan peserta didik. Dengan memperhatikan refleksi dari siklus I, maka dilakukan perencanaan perbaikan-perbaikan pembelajaran yang akan dilakukan pada siklus II agar penelitian mencapai target yang ditentukan. Setelah dilakukan tindakan siklus II terdapat 20 peserta didik atau (87\%) yang memiliki motivasi pada kategori tinggi, sedangkan 3 peserta didik atau $(13 \%)$ memiliki motivasi pada kategori sedang, 0 peserta didik memiliki motivasi pada kategori rendah. Pada kondisi siklus II terdapat 20 peserta didik yang memiliki motivasi pada kategori tinggi. Hasil yang diperoleh pada siklus II ini telah mencapai target yaitu ketuntasan peserta didik mencapai $(87 \%)$.

Pada kondisi hasil belajar sebelum dilakukan tindakan atau pada pra siklus peserta didik yang tuntas hanya sebanyak 10 anak $\operatorname{atau}(43 \%)$ kemudian dilaksanakan siklus I ketuntasan peserta didik meningkat mencapai 15 anak atau $(65 \%)$. Berarti terjadi peningkatan sebanyak (22\%). Akan tetapi hasil yang diperoleh pada siklus I belum memenuhi target sesuai dengan indikator kerja yang telah dibuat yaitu ketuntasan mencapai $(80 \%)$ atau lebih dari keseluruhan peserta didik. Hal ini dikarenakan 
guru belum dapat mengkondisikan kelas secara maksimal. Jadi apabila guru tidak memperhatikan pada peserta didik yang masih bercanda dengan temannya seperti mengganggu peserta didik yang lain, sibuk sendiri dengan kegiatannya. Kemudian peserta didik belum berani menjawab pertanyaan dari guru serta belum berani menyampaikan pendapat ataupun mempresentasikan hasil diskusinya di depan kelas dan menanggapinya. Dengan memperhatikan refleksi dari siklus I, maka dilakukan perencanaan perbaikan-perbaikan pembelajaran yang akan dilakukan pada siklus II agar penelitian mencapai target yang ditentukan. Setelah dilakukan tindakan siklus II, ketuntasan peserta didik mencapai (87\%) dari 23 peserta didik 20 yang tuntas, ini berarti Penelitian Tindakan Kelas dengan menggunakan model Numbered Heads Together (NHT) meningkatkan ketuntasan peserta didik sebanyak (22\%) dibandingkan hasil belajar sebelum dilakukan tindakan. Hasil yang diperoleh pada siklus II ini telah mencapai target yaitu ketuntasan peserta didik mencapai $(87 \%)$.

Dengan menggunakan model pembelajaran Numbered Heads Together (NHT) Proses pembelajaran dimulai dengan guru mengulas kembali pembelajaran yang telah dilaksanakan pada pertemuan 1 mengenai materi pecahan, kemudian dilanjutkan dengan sintagmatik dari model Numbered Heads Together (NHT) yang belum terlaksana pada pertemuan sebelumnya adalah pelaksanaan diskusi evaluasi dalam pembelajaran. Diawali dengan peserta didik kembali membentuk kelompok menjadi 5 peserta didik. Pelaksanaan kegiatan selanjutnya adalah peserta didik diingatkan arahan permainan diskusi yang akan dilaksanakan sesuai dengan model Numbered Heads Together (NHT). Peserta didik memulai kegiatan dengan bertanya mengenai materi yang telah dipejari terhadap salah satu kelompok menjawab pertanyaan sesuai nomor yang telah ditunjuk oleh guru. Kemudian, dari kelompok tersebut berdiskusi secara bersama untuk menentukan jawaban yang terbaik. Nomor yang sudah ditunjuk oleh guru dipersilahkan mengemukakan jawabannya. Namun dalam pelaksanaanya ada kelompok lain yang belum mengerti dari jawaban dari peserta didik yang menjawab, dan peserta didik dari kelompok lain berhak menyanggah dan memberikan jawaban yang menurutnya sesuai dengan pertanyaan. dalam pelaksanaannya apabila terjadi diskusi yang berkepanjangan dan titik temu, maka guru membantu dalam memberikan kesimpulan mana yang yang terbaik dalam menjawab pertanyaan tersebut.

Kegiatan diskusi antar kelompok dilaksanakan selama 15 menit dan tetap dalam pengawasan oleh guru. Guru tetap membantu peserta didik dalam memberikan kesimpulan dalam sebuah masalah. berikutnya adalah sintaks tanya jawab tentang hal-hal yang belum diketahui oleh peserta didik. Guru dan peserta didik meluruskan kesalah pahaman dan memberikan penguatan serta menyimpulkan hasil pembelajaran tentang materi pecahan. Proses pembelajaran diakhiri dengan kegiatan penutup berupa uji soal posttest untuk mengukur tingkat keberhasilan peserta didik dalam belajar dan pemahaman model. Selanjutnya guru memberikan tugas pekerjaan rumah serta memberikan penghargaan kepada kelompok yang menjawab pertanyaan dan aktif dalam pelaksanaan pembelajaran, memberikan motivasi untuk tetap belajar dengan lebih giat, dan mengakhiri kegiatan pembelajaran dengan doa bersama sebelum pulang.

Hasil penelitian ini mendukung penelitian yang telah dilakukan oleh Penelitian yang relevan dengan penelitian ini adalah penelitian yang dilakukan oleh Destiani Pratiwi (2018) yang meneliti tentang Peningkatan Hasil Belajar Matematika Melalui Model Pembelajaran Kooperatif Tipe NHT di SDN Nomporejo. 
2110 Peningkatan moivasi dan hasil belajar matematika peserta didik dengan model NHT - Lely Afni Ikhwandari, Nyoto Harjono, Gamaliel Septian Airlanda

Eliswatus Solekhah (2015) yang meneliti tentang Penerapan Model Pembelajaran Kooperatif Tipe NHT Untuk Meningkatkan Hasil Belajar Siswa Kelas VIII SMP NEGERI 15 Palu Pada Materi Penjumlahan Dan Pengurangan Pecahan Bentuk Aljabar.I Made Hendra Sukmayasa (2013) meneliti tentang Pengaruh Model Pembelajaran Kooperatif Tipe NHT Berbantuan Senam Otak Terhadap Keaktifan dan Prestasi Belajar Matematika. Winarti Dwi Febriani (2017) meneliti tentang Penerapan Pembelajaran Kooperatif Tipe Numbered Heads Together (NHT) Pokok Bahasan Bilangan Pecahan Untuk Meningkatkan Hasil Belajar Siswa. Hasil penelitian dengan menggunakan NHT pada pembelajaran matematika menunjukkan adanya peningkatan proses pembelajaran, terlihat siswa menjadi aktif dan dapat bekerja sama dengan kelompoknya masing-masing, demikian pula perolehan nilai hasil belajar siswa dalam pembelajaran siklus I rata-rata siswa mencapai 70,428 , pada siklus II rata-rata siswa mencapai 76,286, dan siklus III rata-rata siswa mencapai 79,714 atau sebesar 94,286\% siswa yang mencapai nilai KKM. Berdasarkan hasil penelitian tersebut, dapat disimpulkan bahwa penerapan Model Pembelajaran Kooperatif Tipe NHT dapat meningkatkan hasil belajar siswa pada pokok bahasan bilangan pecahan. temuan penelitian ini mendukung penelitian yang dilakukan oleh penulis tentang penelitian tindakan kelas untuk peningkatan motivasi dan hasil belajar matematika. Selanjutnya penelitian yang dilakukan oleh Sachrom Sumardi(2013) meneliti tenteng Upaya Meningkatkan Aktivitas dan Hasil Belajar Matematika melalui Model Pembelajaran Kooperatif Tipe Numbered Heads Together (NHT) pada siswa kelas VII-1 SMP Negeri I Cigombong Kabupten Bogor. Selain mendukung lima hasil penelitian sebelumnya, hasil penelitian ini juga mendukung pernyataan teoritis tentang model
Numbered Heads Together (NHT). Huda (2014:130) Numbered Heads Together (NHT) merupakan varian dari diskusi kelompok. Teknis pelaksanaanya hampir sama dengan diskusi kelompok. Pertama-tama guru meminta peserta didik untuk duduk berkelompok-kelompok. Masing-masing anggota diberi nomor. Setelah selesai guru memanggil nomor untuk mempresentasikan hasil diskusinya. Guru tidak memberitahukan nomor berapa yang akan berpresentasi selanjutnya. Begitu seterusnya hingga semua nomor terpanggil. Pemanggilan secara acak ini akan memastikan semua peserta didik benar-benar terlibat dalam diskusi. Adapun tujuan dari metode pembelajaran Numbered Heads Together (NHT) ini adalah untuk mengembangkan kerja tim, ketrampilan belajar kooperatif, dan menguasai pengetahuan secara mendalam yang tidak mungkin diperoleh bila mereka mencoba untuk mempelajari semua materi sendirian (Trianto, 2010:85). Dari hasil pemaparan, dapat diperoleh kesimpulan bahwa model Numbered Heads Together (NHT) yang peneliti lakukan dapat dikatakan berhasil. Model Numbered Heads Together (NHT) akan dapat menambah motivasi, rasa percaya diri, toleransi, kerjasama dan juga pemahaman materi peserta didik. Hal ini yang menjadikan motivasi dan hasil belajar matematika peserta didik dikelas 4 SD Negeri Gedong 2 Banyu Biru Kabupaten Semarang Tahun Pelajaran 2019/2020 pada materi pecahan menjadi meningkat.

\section{SIMPULAN}

Berdasarkan hasil penelitian dan pembahasan yang telah dipaparkan dapat disimpulkan bahwa penggunaan model Numbered Heads Together (NHT) telah berhasil meningkatkan motivasi dan hasil belajar matematika melalui model Numbered Heads Together (NHT) serta pendekatan-pendekatan 


\section{Peningkatan moivasi dan hasil belajar matematika peserta didik dengan model NHT - Lely Afni Ikhwandari, Nyoto Harjono, Gamaliel Septian Airlanda}

yang disesuaikan dengan pembelajaran matematika serta karakteristik pesera didik pada peserta didik kelas 4 SDN Gedong Biru terbukti. Penerapan model Numbered Heads Together (NHT) dengan sintak membagi peserta didik dalam kelompok, setiap kelompok mendapat nomor, memberikan tugas dan masing-masing kelompok mengerjakannya, mendiskusikan jawaban yang benar dan memastikan tiap anggota kelompok dapat mengerjakannya/ mengetahui jawabannya, memanggil salah satu nomor peserta didik dengan nomor yang dipanggil untuk melaporkan hasil kerjasama mereka, Tanggapan dari teman yang lain, kemudian guru menunjuk nomor yang lain dan membuat kesimpulan, berdampak pada meningkatnya antusias peserta didik ketika proses pembelajaran dan hasil belajar matematika. Peserta didik aktif dalam menggali informasi dan merefleksi pengetahuan sendiri untuk menyelesaikan permasalah dalam mengerjakan soal matematika yang diberikan oleh guru, aktif ketika membangun ulang pengetahuan melalui kegiatan menyenangkan dalam berdiskusi secara individu ataupun berkelompok serta lebih percaya diri ketika bertanya jawab dengan guru ataupun ketika menyampaikan pendapat dalam kegiatan komunikatif.

Hal ini ditunjukkan dengan peningkatan motivasi belajar pra siklus, peserta didik yang berada dalam kategori tinggi sebanyak 5 peserta didik atau $22 \%$ dari jumlah peserta didik. Kemudian setelah dilakukan siklus I, peserta didik yang berada pada kategori tinggi meningkat menjadi 12 peserta didik atau 52\% selanjutnya Persentase ini meningkat kembali pada siklus II peserta didik yang berada dalam kategori tinggi sebanyak 20 peserta didik dengan persentase sebesar $87 \%$. Hasil belajar matematika berdasarkan ketuntasan belajar dengan KKM $\geq 70$. Hasil analisis diketahui bahwa dari 23 peserta didik yang tuntas sebelum tindakan adalah 10 peserta didik (43\%). Setelah diberikan tindakan pada siklus I terjadi peningkatan jumlah ketuntasan peserta didik menjadi 15 peserta didik (65\%). Setelah diberikan tindakan pada siklus II, terjadi lagi peningkatan jumlah ketuntasan menjadi 20 peserta didik (87\%). peserta didik yang belum tuntas sebelum diberikan tindakan adalah 13 peserta didik $(57 \%)$. Setelah diberikan tindakan pada siklus I, berkurang menjadi 8 peserta didik (35\%). Setelah dilaksanakan lagi tindakan pada siklus II, menjadi 3 peserta didik (13\%) yang belum tuntas. Penggunakan model Numbered Heads Together (NHT) dalam kegiatan pembelajaran dapat meningkatkan hasil belajar matematika peserta didik dikelas 4 SD Negeri Gedong 2 Banyu Biru Kabupaten Semarang Tahun Pelajaran 2019/2020 yaitu dengan menerapkan pembelajaran sesuai dengan langkah-langkah pembelajaran secara urut. Pembelajaran menggunakan model Numbered Heads Together (NHT) salah sutu model pembelajaran kooperatif yang melibatkan aktivitas seluruh peserta didik yang memiliki kemampuan, jenis kelamin dan suku atau ras yang berbeda. Dan juga suatu model pembelajaran koopratif dimana bagiannya terdiri dari penyampaian materi secara klasikal, pengelompokan dan penghargaan kelompok. Model Numbered Heads Together (NHT) akan dapat menambah motivasi, rasa percaya diri, toleransi, kerjasama dan juga pemahaman materi peserta didik

\section{DAFTAR PUSTAKA}

Ahmadi, Abu dan Supriyono, Widodo. 2013. Psikologi Belajar. Jakarta : PT Rineka Cipta

Destiani Pratiwi, 2018 Peningkatan Hasil Belajar Matematika Melalui Model Pembelajaran Kooperatif Tipe NHT di SDN Nomporejo. Jurnal Pendidikan Guru Sekolah Dasar Edisi 11 Tahun ke-7 2018 
2112 Peningkatan moivasi dan hasil belajar matematika peserta didik dengan model NHT - Lely Afni Ikhwandari, Nyoto Harjono, Gamaliel Septian Airlanda

Dimayanti,Mudjiono .2013. Belajar dan Pembelajaran. Jakarta: Rineka Cipta

Eliswatus Solekhah.2015. Penerapan Model Pembelajaran Kooperatif Tipe NHT Untuk Meningkatkan Hasil Belajar Siswa Kelas VIII SMP NEGERI 15 Palu Pada Materi Penjumlahan Dan Pengurangan Pecahan Bentuk Aljabar. Jurnal Elektronik Pendidikan Matematika Tadulako, Volume 02 Nomor 03, Maret 2015

Hamzah B Uno. 2013. Teori motivasi dan pengukurannya. Jakarta. Bumi Aksara

Hamzah B Uno. 2013. Teori motivasi dan pengukurannya. Jakarta. Bumi Aksara

Huda,Miftahul.2013.Model-Model Pengajaran dan Pembelajaran.Yogyakarta: Penerbit Pustaka Pelajar.

Huda,Miftahul.2014.Model-Model Pengajaran dan Pembelajaran.Yogyakarta: Penerbit Pustaka Pelajar.

I Made Hendra Sukmayasa.2013.Pengaruh Model Pembelajaran Kooperatif Tipe Nht Berbantuan Senam Otak Terhadap Keaktifan Dan Prestasi Belajar Matematika.e-Journal Program Pascasarjana Universitas Pendidikan Ganesha Jurusan Pendidikan Dasar (Volume 3 Tahun 2013)

Majid. 2014. Strategi Pembelajaran. Bandung: Remaja Rosdakarya

Ngalimun. 2014. Strategi dan Model Pembelajaran. Aswaja pressindo. Yogyakarta

Ngatini. 2012. Peningkatan Keaktifan dan Hasil Belajar Matematika Tentang Fungsi Melalui Model Pembelajaran Numbered Heads Together Bagi Siswa SMP. Jurnal Manajemen Pendidikan, 7(2): 151-159. SMP Negeri 1 Purwodadi

Purwanto.2013. Evalusi Hasil Belajar. Yogyakarta: Pustaka Pelajar.

Sachrom Sumardi.2013.Upaya Meningkatkan Aktivitas dan Hasil Belajar Matematika melalui Model Pembelajaran Kooperatif Tipe Numbered Heads Together (NHT) pada siswa kelas VII-1 SMP Negeri I Cigombong Kabupten Bogor. Jurnal Teknologi Pendidikan, Vol 2, No 1 (2013)

Sardiman. 2012. Interaksi dan Motivasi Belajar Mengajar. Jakarta: Radjawali.
Sardiman.2011.Interaksi dan Motivasi Belajar Mengajar. Jakarta: PT. Raja Grafindo Persada.

Slameto.2015.Metodologi Penelitian \& Inovasi Pendidikan. Salatiga: Satya Wacana University Press.

Sudjana, N. 2013. Penilaian Hasil Proses belajar Mengajar. Bandung: PT Remaja Rosdakarya.

Suhana, Cucu. 2014. Konsep Strategi Pembelajaran. Bandung. PT. Refika aditama

Suprijono, Agus. 2013. Cooperative learning. (Yogyakarta:Pustaka Pelajar).

Suprijono. 2012. Cooperative Learning. Yogyakarta: Pustaka Pelajar

Susanto,2013.Teori Belajar Dan Pembelajaran Di Sekolah Dasar. Jakarta: Kencana

Trianto.2010.Mendesain Model Pembelajaran Inovatif -Progresif. Jakarta: Kencana Prenada Media Group.

Winarti Dwi Febriani.2017.Penerapan Pembelajaran Kooperatif Tipe Numbered Heads Together (NHT) Pokok Bahasan Bilangan Pecahan Untuk Meningkatkan Hasil Belajar Siswa. Jurnal Forum Didaktik Vol 1 No 2 Edisi September 2017

Yamin, M.2012.Paradigma baru pembelajaran. Jakarta: Gaung Persada Press Group. 